\title{
Research on the Cultivation of Workmanship of Higher Vocational College Students Against the Backdrop of Internet Plus
}

\author{
CHANG Linyun \\ Tianjin University, School of Education \\ Tianjin, China \\ 997928320@qq.com
}

\author{
ZHU Shiming \\ Tianjin University, School of Education \\ Tianjin, China \\ 574815817@qq.com
}

\begin{abstract}
In order to implant the idea and method of workmanship into the talent training scheme of higher vocational colleges and accelerate the construction of industrial workers in the new period, the paper explains the new demands of Internet Plus on industrial workers and the present cultivation situation of students in higher vocational colleges through literature research, and provides the cultivation path of workmanship. Under the background of Internet Plus, workmanship should pay more attention to innovation and open cooperation. However, the cultivation of students in higher vocational colleges needs to be strengthened, so it is necessary for higher vocational colleges to actively promote curriculum reform, strengthen the construction of campus culture, make full use of school-enterprise cooperation and set up a practical platform for students to realize the whole course and overall education. The innovation lies in the combination of Internet Plus and vocational education, as well as new suggestions for industrial workers.
\end{abstract}

Keywords-Internet Plus; Workmanship; Higher vocational college; Fostering path

\section{INTRODUCTION}

Under the background of Internet Plus, promoted by innovation 2.0 in knowledge society, the new generation of information technology, such as Internet of things, cloud computing and big data, is developing rapidly. Internet has gradually penetrated into the product manufacturing, consumption and other fields, leading the new normal economy of innovation-driven development. In the key period of accelerating the optimization of traditional industry and the upgrade of industrial structure, human resource is still the first resource for economic development. We have come to realize the importance of workmanship whose content is "The Pursuit of Excellence" in this era.

Premier Li Keqiang stressed the importance of workmanship in his reports on the work of the government at the two sessions in 2017, "we will promote workmanship and foster a culture of workmanship where workers have a strong work ethic and tirelessly seek improvement. We will refine our incentive mechanisms and see great numbers of Chinese workers exemplify workmanship and more Chinese brands enjoy international recognition. We will usher in an era of quality for economic development in China."[1] "Workmanship" not only represents the professional spirit of dedication, concentration and innovation, but is also the synonym of professional ethics and vocational capability. As the representative of advanced productive forces, industrial workers need skilled talents with workmanship to meet the needs of the times.

\section{INTERNET PLUS'S NEW DEMANDS ON INDUSTRIAL WORKERS}

Recently, the CPC Central Committee and the State Council have promoted the construction of the ranks of industrial workers by issuing the "Reform Plan for the Construction of Industrial Workers in the New Era," which centered on 5 factors such as strengthening and improving the ideological and political construction of industrial workers, building a system for the formation of industrial workers' skills, the use of the Internet to promote the construction of industrial workers, innovation of industrial workers' development system, as well as strengthening the support capacity for the construction of industrial workers [2]

In the era of Internet Plus, the traditional enterprises were faced with the loss of traditional advantages as well as the drastic change of the competition pattern. At present, there is an imbalance in the structure of the skilled talents in our country: the imbalance of the industrial distribution, for example, there are more types of work in the traditional machinery processing industry, while less in new industry and modern manufacturing industry [3]. In order to cultivate a worker group with superb professional skills, the development of Internet Plus puts forward new goals and requirements for workers. 


\section{A. Possessing the "Maker Spirit" and Open Collaboration Spirit}

With the deepening of the maker movement, "Maker" has come to have a broader meaning: anyone who can turn ideas with considerable technical challenges into reality. Even with the same traditional creative activities as carpentry, cooking and planting, there is a big difference between them and their predecessors because of the Internet.

Under the background of Internet Plus, cross-border ecommerce has developed rapidly. Platforms such as Alibaba have given traditional craftsmen unlimited opportunities and possibilities. They can provide customized manufacturing services based on user-demand information provided by the Internet platform. At the same time, the rapid development of manufacturing technology also provides a tool for transforming creativity into reality. With the development and popularization of advanced manufacturing technology, the cost of transforming ideas into products will be greatly reduced. In the context of the Internet Plus, the sales platform is becoming more open, and the manufacturing technology is becoming more and more equal. Therefore, innovation has become an important indicator for performance appraisal of the manufacturers, and creativity has also become an indispensable core of every industry. "Maker Spirit" is the spirit of workmanship that evolves in the Internet information era, which embodies a kind of unremitting efforts and an attitude of pursuing innovation. Meanwhile, the spirit of "Maker Spirit" highlights the new connotation of the era that artisans' spirit is endowed with, that is, "Self-reliance, Personality Development" at the individual level, "Iterative Innovation, Coordinated Development" at the industry level, and "Heavy Industrial Equipment and Strategic Development" at the national level. "Maker Spirit" is one of the indispensable qualities of excellent industrial workers under the background of Internet Plus.

The "Industry 4.0" put forward by the German government is one of the new concepts on Internet. In the meantime, China launched the strategy of "Made in China 2025", and put forward the supply-side structural reform to realize the end-toend interface between the manufacturing end and the consumer side. It can be seen that the future trend of economic development is that a large number of industries will break the traditional barriers to production and marketing. Therefore, open collaboration is the spiritual soul of the future economic development. As direct participants in the production process, industrial workers must have an open and inclusive attitude as well as the courage to cooperation.

\section{B. Improving Personal Media Literacy and Informatization Literacy}

Modern industrial workers are different from the old workmen. All that the latter need to do is to specialize in their own workmanship. While the contemporary industrial workers are engaged in hard work, they should always pay attention to the latest development trend of media information and technology, and keep up with the pace of the development of the times, so as to ensure the advancement and practicability of technology. In the era of Internet Plus, only when we have the most advanced, comprehensive, scientific and effective information resources and combine with the technical means of workers can we truly play the technological role. Therefore, contemporary industrial workers must enhance their media literacy and information literacy.

Media literacy refers to the ability of citizens to acquire, analyze, evaluate and transmit various forms of information, with emphasis on the cognitive process of information. In 1992 , the Center for Media Literacy Research in the United States defined media literacy as the ability to choose, question, understand, evaluate, create and produce the information as well as the ability of speculative responsiveness that people show when they face various kinds of information in different media [4]. The information literacy required by industrial workers includes: 1. mastering basic information knowledge, good at collecting and sorting information through the Internet, and able to analyze and synthesize information; 2.having strong information consciousness, good at using public information resources, and trying to follow the trend of the times; 3.abiding by the information law, obeying the information policy, and having the information ethics. Only by adapting to the current situation of modern information society can industrial workers broaden their horizons, activate their thinking, seize opportunities, maintain good insight and thinking ability.

\section{The PRESENT SituAtion AND PROBLEMS OF WORKMANSHIP CULTIVATION IN HIGHER VOCATIONAL COLLEGES}

As the most closely related type of education with economic and social development, vocational education undertakes the important task of cultivating a large number of technical talents for the country. China's vocational colleges have always attached importance to the training of students' vocational skills, but the cultivation of students' professional quality and professional ideas are often ignored, which is related to the poor professional quality and week professional ideas of the industrial workers in our country currently. At present, following problems exist in the cultivation of students' workmanship in vocational colleges. 


\section{A. Insufficient Combination of Workmanship Cultivation and Professional Education}

Professional education should be an important way for workmanship to integrate into classroom teaching. Most of the time students in vocational colleges are taught in specialized courses. Therefore, to cultivate the workmanship of students should take the teaching of specialized courses as the main channel. But at present, the main content of the teaching in most higher vocational colleges in our country is still classroom teaching and knowledge indoctrination. The socalled practical training is to let the students scratch the surface of the capabilities, not to mention the requirement to guide them to comprehend the workmanship.

The combination of workmanship and professional education is not high in higher vocational colleges. The main performances are as follows: 1. vocational colleges fail to make full use of the talent training mode of cooperation between school and enterprise to help students understand the true workmanship, and fail to establish strict professional standards in the process of practice; 2 . at present, many vocational colleges and universities are not fully integrated with the needs of enterprises and markets in the course of setting up professional courses and implementing teaching. 3. In the "2+1" talent training mode in higher vocational colleges, students receive major study in theory courses in the first two years, and take part in fixed post practice in the last year. In this mode, teaching and learning, theory and practice are still separated, which is disadvantageous to the cultivation of students' workmanship. To sum up, we should fully understand the importance and existing problems of "Workmanship" in enhancing professional skills and professionalism, so as to prevent students' cognition from being superficial, one-sided and vulgar.

\section{B. Deficiency of Ideological and Political Education and Lack of Campus Culture}

For a long time, many higher vocational colleges have focused their development on the cultivation of students' skills, but neglected the cultivation of their moral and cultural qualities, which virtually makes the students utilitarian and technology-focused. Many courses concerning ideological and political education as well as humanistic spirit have been marginalized. Students trained under this concept have knowledge but lack for moral culture, have education background but lack for learning, lack for humanistic connotations as well as the understanding and personal experience of workmanship. However, what is worth paying attention to is that campus culture is one of the most important components of higher vocational education, which plays an important role in enriching the life of teachers and students, reconciling interpersonal relationships and shaping the personality of teachers and students. At present, the construction of campus culture in many colleges and universities is characterized by extensive form-homogenization of campus culture construction, too much imitation, little innovation, and lack of overall systematic plan for campus culture construction concerning workmanship. It is difficult for students to identify with campus culture and is not conducive to making the workmanship deep in mind.

\section{THE SPECIFIC PATH OF CUlTIVATING STUDENTS' WORKMANSHIP IN HIGHER VOCATIONAL COLLEGES UNDER THE BACKGROUND OF INTERNET PLUS.}

"Large Quantity but Poor Quality" is the existing state of industrial workers, which determines it is difficult for them to adapt to the new business situation of Internet Plus. As the primary position of cultivating industrial workers and other front-line workers, higher vocational colleges need to shoulder the responsibility of educating people. They should start from two dimensions simultaneously---education in the whole course and overall education to cultivate the students' professional spirit with workmanship as the core. Education in the whole course means the cultivation of workmanship shall be throughout each link of professional education, ideological and political education as well as practical education from the entrance to graduation; overall education means that all educators should pay attention to the cultivation of workmanship.

\section{A. Professional Curriculum Design Compatible with Internet Plus}

Through the optimization of curriculum system as well as the design and application of teaching mode, the reform of talent training mode is promoted, and the understanding and recognizing of workmanship are propelled. The professional quality and attitude of the workman are throughout the whole process of the skilled talent cultivation. The dimensions of knowledge and skills, process and method, emotion, attitude and value shall be taken into account to determine the curriculum objectives and be committed to integrate "Workmanship" into every talent training link. First of all, we should set up professional platform courses to teach students according to their aptitude. Internet Plus is used to expand the form of online and offline public elective courses to meet the personality development of students. Secondly, we should pay attention to the integration of the profession cultivation education with "Workmanship" as core into all kinds of platform courses to meet the individual needs of students and lay the foundation for the students' career development at the same time. Internet management can be applied for wisdom teaching and wisdom management. Wisdom teaching is to build and share educational resources through the Internet online education platform, such as Mooc, Flipped Class, Micro Learning Resource and so on [5]. By making use of the deep fusion of modern information technology and educational resources, we should strengthen the combination of curriculum mode and Internet Plus's new form of work, as well as strengthen the close combination of professional course setup and the market. 


\section{B. Make Full Use of the Cooperation between Schools and Enterprises to Set up a Practical Education Platform}

Practical education has always been the main position of training students in higher vocational colleges. In order to cultivate the students' workmanship in the process of practice, first of all, higher vocational colleges should make full use of school enterprise cooperation to create a multi-level practical platform, deepen the cooperation between school and enterprise, take the demand and benefit of the enterprise as the breakthrough point, combine different professional features, lead the factory to enter the school, form good operation mechanism of the cooperation between the school and the enterprise. In the process of choosing the cooperation object, higher vocational colleges should try their best to select enterprises with healthy corporate culture and humanistic background, so that students can be well nurtured and cultivated. Through adopting the "Bi- tutor" talent training model, we can pass on the vocational skills together, and jointly cultivate the students' professional quality and workmanship [6]. Secondly, combining with the connotation of "innovation and creation" contained in the workmanship, the students are trained in thinking, guided in career planning, and received by simulation training of innovation and entrepreneurship. By building a competition platform, students can further combine their professional skills to understand the workmanship. Finally, establish a set of perfect innovative teaching management and evaluation system. A set of practical, scientific and reasonable evaluation index should be set up for comprehensive and objective evaluation of the culture efficiency of students' workmanship in different stages by the school, enterprise and society in union.

\section{Strengthening Ideological and Political Education as well as Campus Culture Construction}

Campus culture mainly refers to the unique humanistic environment and cultural atmosphere of the school. Excellent campus culture has a quiet influence on students' outlook on life and values. Therefore, higher vocational colleges should strengthen the construction of campus culture and combine the cultivation of workmanship with socialist core values. First of all, we should clarify the value orientation of the students' daily behavior norms, ask them to start from everyday small details and strictly develop their traits of being civilized. Teacher and Student Administration should carry out routine supervision, regularly conduct civilization assessment, and guide students to pay attention to hygiene and stress on discipline. Secondly, the management culture should be built to support workmanship.
The management culture should be built in the course of carrying out teaching activities to transport qualified graduates with workmanship for the enterprise, and put forward different learning goals and requirements for students of different majors, formulate strict practice and training procedures, and require teachers to urge each student to understand workmanship and internalize it into conscious behavior in the process of imparting knowledge. Finally, system culture and effective reward mechanism that can support workmanship should be built. Strengthen the incentive mechanism for the students with the spirit of workmanship, and highlight the students' ability in the system of scholarship, honor evaluation and so on. At the same time, higher vocational colleges should popularize the concept of occupational equality and common vocational thought to help some students to remove the inferiority mentality of vocational education.

\section{CONCLUSION}

The cultivation of workmanship has become an important development strategy of our country, and it is also an important task entrusted to us by the times. As the main force in higher education, higher vocational education is duty-bound to cultivate students' workmanship, takes it as the core of professional spirit and deeply embeds its cultivation conception in the heart of every teacher and every student. What's more, it should make full use of the advanced technology and management platform in the context of Internet Plus to cultivate greater craftsman as well as inheritors and builders of the new era.

\section{REFERENCES}

[1] Li Keqiang 2017 Government Work Report [R] http://www.china.org.cn/chinese/2017-03/17/content_40466623.htm. (In Chinese)

[2] Ministry of Land and Resources of the People's Republic of China, "Reform plan for the construction of industrial workers in the new era", [EB/OL]. 2017-6-21. (In Chinese)

[3] People's Daily commentator, Setting up High-quality Industrial Worker Teams, [N]. People's Daily, 2017-7-1(10). (In Chinese)

[4] Zhang Qiuyan, "Research on the development of foreign media education" [J]. Journal of International Communication, 2005(2): 10-13. (In Chinese)

[5] Zha Guoshuo, "The modern value implication of workmanship" [J]. Vocational \& Technical Education Forum, 2016 (7) 74-75.

[6] Wang Liyuan, "Study on the necessity and feasibility of cultivating students' workmanship in higher vocational education" [J]. Vocational \& Technical Education Forum, 2014, (22):66-69. (In Chinese) 